\title{
Respon Pertumbuhan dan Hasil Padi Gogo yang dipengaruhi oleh Pemberian Biochar dan Pupuk Hayati
}

\author{
Betty Natalie Fitriatin ${ }^{1)}$, Dzakaria Yogaswara 2 ), Tien Turmuktini2), Emma Trinurani Sofyan ${ }^{1}$, \\ dan Anny Yuniarti ${ }^{11}$ \\ 1)Departemen Ilmu Tanah dan Sumberdaya Lahan, Fakultas Pertanian Universitas Padjadjaran \\ Jl. Raya Bandung Sumedang Km 21 Jatinangor, Sumedang \\ 2) Fakultas Pertanian Universitas Winaya Mukti \\ Jl. Raya Bandung Sumedang No.29, Tanjungsari, Sumedang
}

Korespondensi: betty.natalie@unpad.ac.id

\begin{abstract}
One of the efforts to increase crop yield based in sustainable agriculture is through the utilization of microbial inoculants (biofertilizers) and soil conditioners. Biofertilizer is an ingredient that contains beneficial microbial inoculants to increase soil nutrient availability for plants. Biochar has been recognized as a soil conditioner by improving soil physical, chemical, and biological properties as well as in retaining nutrients, thereby enhancing plant growth. However, the research regarding the effect of the combination between biofertilizers and biochar on growth and yield of upland rice are still at scarce. The field experiment was conducted to determine the impact of biofertilizers and biochar on growth and yield of upland rice in Andisols at Pasir Talang village in Rancakalong district, Sumedang, West Java. This experiment used a Randomized Block Design (RBD) consisted of six treatments and four replicates. Biofertilizers consisted of N-fixer bacteria (Azotobacter chroococum, Azospirillum sp.) and phosphate-solubilizer microbes (Pseudomonas mallei, P. cepaceae, Aspergillus niger and Penicillium sp.). The treatments were combination of biochar $\left(2,4\right.$, and $\left.6 t \mathrm{ha}^{-1}\right)$ and biofertlizers ( 0 and $50 \mathrm{~kg} \mathrm{ha}^{-1}$. The result of experiment revealed that combination of biochar and biofertilizers increased the growth and yield of upland rice significantly. The application $4 t \mathrm{ha}^{-1} \mathrm{of}$ biochar and 50 $\mathrm{kg} \mathrm{ha}^{-1}$ of biofertilizers gave the best yield of 5,81 $\mathrm{tha}^{-1}$.
\end{abstract}

Key words: biochar, biofertilizers, uplandrice

\section{PENDAHULUAN}

Padi (Oryza sativa L.) merupakan komoditas penting sebagai bahan makanan pokok di Indonesia. Sejalan dengan peningkatan jumlah penduduk akan menyebabkan kebutuhan beras juga meningkat. Berdasarkan data Statistik Pertanian (2018) dalam kurun waktu tahun 2015-2017 produksi padi terus mengalami peningkatan, namun dari sisi produktivitas padi yang ditanam di lahan kering mengalami penurunan. Produktivitas padi tahun 2015 sebesar 5,34 ton/ha, tahun 2016 menjadi 5,24 ton ha-1, dan pada tahun 2017 hanya mencapai 5,16 ton ha-1.

Produktivitas tanaman padi yang rendah pada umumnya disebabkan masalah fisik, biologi dan kimia tanah. Peluang pengembangan padi gogo dilahan kering iklim basah dan iklim kering di Indonesia masih cukup luas. Upaya meningkatkan produksi padi terumata padi gogo yang ditanam di lahan kering perlu dilakukan secara berkelanjutan yaitu dengan memanfaatkan sumber daya hayati diantaranya pupuk hayati dan amelioran.

Upaya yang dapat dilakukan untuk mengatasi permasalahan produktivitas lahan kering untuk pertanaman padi gogo secara berkelanjutan dapat dilakukan dengan pengaplikasian pupuk hayati, agen biologis dan amelioran organik Pupuk hayati merupakan inokulan berbahan aktif berupa organisme hidup dalam bentuk cair atau padat yang memiliki kemampuan untuk memobilisasi, memfasilitasi dan meningkatkan ketersediaan hara tidak tersedia menjadi bentuk tersedia melalui proses biologis (Rao, 1994). 
Pemberian pupuk hayati berupa konsorsium bakteri pelarut $\mathrm{P}$ dan pemfiksasi $\mathrm{N}$ mampu meningkatkan kandungan hara $\mathrm{N}$ dan $P$ tanah serta pertumbuhan padi gogo pada tanah Ultisols (Fitriatin, dkk., 2019). Mikroba dalam pupuk hayati dapat ditingkatkan aktivitasnya dengan memberikan sumber energi untuk pertumbuhannya.

Biochar merupakan bahan kaya karbon hitam yang berasal dari pemanasan biomassa $\left(250-700^{\circ} \mathrm{C}\right)$ dengan suplai oksigen terbatas (pyrolysis) (Lehmann dan Joseph, 2009). Biochar atau arang sudah sejak lama dikenal di Indonesia, terutama sebagai sumber energi (bahan bakar dan sumber panas). Akhir-akhir ini biochar digunakan di bidang pertanian sebagai pembenah tanah. Menurut Rajakumar da Sankar (2016), biochar dapat mempengaruhi sifat fisik, kimia dan biologi tanah.

Liu et al. (2014) melaporkan bahwa, aplikasi biochar $40 \mathrm{t} \mathrm{ha}^{-1}$, kestabilan agregat tanah $(>0,25 \mathrm{~mm})$ pada lapisan tanah $0-15 \mathrm{~cm}$ mengalami peningkatan yang sangat tajam dibandingkan dengan perlakuan lain, terutama agregat makro dengan ukuran partikel lebih besar dari $>2 \mathrm{~mm}$. Aplikasi biochar juga dapat menurunkan bobot isi tanah (Chan, et al., 2007), meningkatkan KTK tanah (Peng, et al., 2011). Aktivitas enzim urease and $\beta$ glucosidase meningkat secara signifikan akibat pemberian biochar dibandingkan dengan kontrol (Denise et al., 2014). Pemberian amelioran berupa biochar merupakan salah satu upaya mengoptimalkan kinerja pupuk hayati. Oleh karena itu diperlukan penelitian yang bertujuan untuk mengetahui pengaruh pemberian biochar dan pupuk hayati terhadap pertumbuhan dan hasil padi gogo.

\section{METODOLOGI}

Percobaan dilaksanakan di Kebun Petani Desa Pasir Talang Kecamatan Rancakalong Kabupaten Sumedang dengan ketinggian 894 meter di atas permukaan laut pada bulan Mei sampai bulan September 2019 pada tanah ordo Andisols. Bahan yang digunakan adalah padi Gogo Varietas Luhur 2, arang tempurung kelapa dibuat Biochar, pupuk hayati. Formulasi pupuk hayati berupa konsorsium (Pseudomonas cepaceae, Azotobacer chroococum, A. vilandii, Azospirilum sp., Penicillium sp., Acitenobacater) dalam bentuk padat dengan bahan pembawa campuran gambut da kompos (1:1), pupuk N (Urea), $\mathrm{P}$ (SP-36), $\mathrm{K}(\mathrm{KCl})$, dan kompos jerami.

Rancangan percobaan menggunakan Rancangan Acak Kelompok (RAK) dengan 6 perlakuan dan 4 ulangan. Perlakuan dalam percobaan ini adalah biochar $\left(2,4\right.$, dan 6 t.ha $\left.^{-1}\right)$ dan kombinasi biochar dengan pupuk hayati (50 kg.ha-1). Perbedaan pengaruh rata-rata perlakuan dilakukan dengan uji $\mathrm{F}$ pada taraf $5 \%$ dan apabila terdapat perbedaan rata-rata perlakuan yang nyata maka pengujian dilanjutkan dengan uji lanjut jarak berganda Duncan pada taraf nyata $95 \%$.

Penanaman dilakukan pada lahan percobaan ukuran petak 1 x 1,2 m dan jarak tanam $20 \times 20 \mathrm{~cm}$. Lubang tanam dibuat sedalam $5 \mathrm{~cm}$ dengan sistem tugal sehingga terdapat populasi per petak percobaan 30 tanaman. Benih yang ditanam adalah benih yang sudah diseleksi dan diuji daya kecambahnya serta sudah dikecambahkan setelah kotiledon nampak keluar $\pm 1 \mathrm{~cm}$ sehingga benih siap di tanam langsung pada lahan percobaan.

Biochar dan pupuk hayati diberikan pada saat tanam sesuai dengan dosis perlakuan yaitu Biochar 2 ton ha-1 (340 g). Biochar 4 ton ha-1 $(680 \mathrm{~g})$, biochar 6 ton ha-1 (1020 g) dan pupuk hayati dengan dosis $50 \mathrm{~kg} \mathrm{ha}^{-1}$. Respon yang diamati untuk diuji statistic yaitu tinggi tanaman (pada 10, 20, 30, 40, 50, 60 hari setelah tanam/HST) nisbah pupus akar (pada 30 HST), jumlah anakan produktif (pada 120 HST), bobot gabah kering giling dan bobot 1.000 butir (pada saat panen). 


\section{HASIL DAN PEMBAHASAN}

\subsection{Analisis Tanah Sebelum Percobaan}

Tanah yang digunakan sebagai media tanam padi gogo termasuk ordo Andisols memiliki tekstur tanah lempung berdebu dengan $\mathrm{pH}$ tanah 5,8 yang tergolong dalam kriteria agak masam dengan kandungan Corganik sedang $(2,78 \%)$. Tanah ini memiliki Ntotal sebesar $0,12 \%$ tergolong sedang juga kandungan $\mathrm{P}_{2} \mathrm{O}_{5}$ potensial $\left(169,34 \mathrm{mg} 100 \mathrm{~g}^{-1}\right)$ tergolong sedang sedangkan kandungan $\mathrm{P}_{2} \mathrm{O}_{5}$ tersedia Bray $1\left(173,4 \mathrm{mg} 100 \mathrm{~g}^{-1}\right)$ dan $\mathrm{K}_{2} \mathrm{O}$ (54,99 mg $100 \mathrm{~g}^{-1}$ ) termasuk kriteria rendah. Kapasitas tukar kation tanah ini tergolong sedang yaitu sebesar $27,05 \mathrm{cmol} \mathrm{g}^{-1}$ ).

Berdasarkan hasil analisis sebelum percobaan, tingkat kesuburan tanah ini tergolong rendah karena kandungan unsur hara makro tergolong rendah sampai sedang. Oleh karena itu diperlukan perbaikan hara untuk menunjang pertumbuhan tanmaman. Penambahan pupuk hayati dan amelioran akan memperbaiki kualitas tanah sehingga mampu meningkatkan pertumbuhan tanaman.

\subsection{Pertumbuhan dan Hasil Tanaman}

Hasil analisis statistik menunjukan bahwa pemberian biochar yang dikombinasikan dengan pupuk hayati meningkatkan tinggi tanaman secara signifikan pada 10, 20, 30 dan 40 HST (Tabel 1). Aplikasi 4 ton.ha-1 ${ }^{-1}$ biochar dan pupuk hayati $50 \mathrm{~kg} \mathrm{ha}^{-1}$ pada $10 \mathrm{HST}$ mampu meningkatkan tinggi tanaman hingga $25 \%$ dibandingkan hanya biochar saja.

Tabel 1 Pengaruh biochar dan pupuk hayati terhadap tinggi tanaman umur 10 HST, 20 HST, 30 HST, 40 HST, 50 HST, 60 HST

\begin{tabular}{lllllll}
\hline \multirow{2}{*}{ Perlakuan } & \multicolumn{5}{c}{ Tinggi Tanaman (cm) } \\
\cline { 2 - 6 } & $10 \mathrm{HST}$ & $20 \mathrm{HST}$ & $30 \mathrm{HST}$ & $40 \mathrm{HST}$ & $50 \mathrm{HST}$ & $60 \mathrm{HST}$ \\
\hline Biochar 2 ton ha-1 & $10,53 \mathrm{a}$ & $17,64 \mathrm{a}$ & $23,45 \mathrm{a}$ & $38,29 \mathrm{a}$ & $47,79 \mathrm{a}$ & $62,15 \mathrm{a}$ \\
Biochar 4 ton ha-1 & $10,99 \mathrm{a}$ & $17,94 \mathrm{bc}$ & $25,14 \mathrm{ab}$ & $40,00 \mathrm{ab}$ & $49,19 \mathrm{a}$ & $63,20 \mathrm{a}$ \\
Biochar 6 ton ha-1 & $11,25 \mathrm{a}$ & $19,14 \mathrm{ab}$ & $25,23 \mathrm{a}$ & $39,45 \mathrm{a}$ & $49,23 \mathrm{a}$ & $63,88 \mathrm{a}$ \\
Biochar 2 ton ha-1 pupuk hayati $^{-1}$ & $11,77 \mathrm{ab}$ & $19,82 \mathrm{c}$ & $26,97 \mathrm{~b}$ & $40,43 \mathrm{ab}$ & $51,28 \mathrm{a}$ & $63,73 \mathrm{a}$ \\
Biochar 4 ton ha-1+ pupuk hayati & $13,72 \mathrm{c}$ & $21,29 \mathrm{~d}$ & $28,05 \mathrm{~b}$ & $42,78 \mathrm{~b}$ & $51,57 \mathrm{a}$ & $65,14 \mathrm{a}$ \\
Biochar 6 tob ha-1+ pupuk hayati & $12,16 \mathrm{bc}$ & $20,02 \mathrm{~cd}$ & $27,00 \mathrm{~b}$ & $41,93 \mathrm{~b}$ & $50,77 \mathrm{a}$ & $65,14 \mathrm{a}$ \\
\hline
\end{tabular}

Keterangan : Angka rata-rata yang diikuti huruf sama pada setiap kolom yang sama, menunjukkan berbeda tidak nyata berdasarkan Uji Jarak Berganda Duncan pada taraf nyata $95 \%$.

Berdasarkan data pada Tabel 1 menunjukkan bahwa secara umum pemberian biochar tanpa pupuk hayati tidak signifikan meningkatkan tinggi tanaman. Hal ini menunjukkan bahwa kombinasi perlakuan biochar dan pupuk hayati lebih baik dalam meningkatkan pertumbuhan tanaman padi gogo. Hal ini didukung oleh hasil penelitian Youseef et al. (2017) bahwa perlakuan kombinasi pupuk hayati + biochar + pupuk mineral (NP) mampu meningkatkan secara nyata pertumbuhan dan hasil tanaman bawang putih dibandingkan perlakuan tunggal hanya pupuk hayati atau biochar atau pupuk mineral saja. Arabi et al. (2018) melaporkan bahwa pemberian biochar dan pupuk hayati mampu meningkatkan hasil kedelai hingga $51 \%$ dibandingkan dengan kontrol.

Aplikasi biochar dosis 4-6 ton ha-1 yang dikombinasikan dengan pupuk hayati $50 \mathrm{~kg} \mathrm{ha-}$ 1 mampu meningkatkan secara nyata nisbah pupus akar (Tabel 2). Peningkatan nisbah pupus akar pada dosis 4 ton ha-1 + pupuk hayati mencapai 42,5\% sedangkan dosis bochar 6 ton ha $^{-1+}$ pupuk hayati mencapai 119,8 \% dibandingkan perlakuan tunggal biochar saja dengan dosis yang sama. Hal ini menunjukkan bahwa penambahan pupuk hayati mampu meningkatkan nisbah pupus akar tanaman padi gogo. 
Bakteri pemfiksasi N (Azotobacer chroococum, A. vilandii, dan Azospirilum sp.) dan mikroba pelarut $\mathrm{P}$ (Pseudomonas cepaceae dan Penicillium sp.) yang terkandung dalam pupuk hayati mampu meningkatkan fotosintat yang ditunjukkan dengan meningkatnya bagian atas tanaman (tajuk) dibandingkan bagian akar atau meningkatkan nisbah pupus akar. Hasil penelitian Egamberdieva et al. (2016) menunjukkan aplikasi biochar yang dikombinasikan dengan plant growth promoting bacteria (PGPR) mampu meningkatkan shoot root ratio.

Tabel 2 Pengaruh biochar dan pupuk hayati terhadap nisbah pupus akar (NPA)

\begin{tabular}{|c|c|c|}
\hline Perlakuan & $\begin{array}{c}\text { Nisbah } \\
\text { Pupus Akar }\end{array}$ & $\begin{array}{l}\text { Anakan } \\
\text { Produktif }\end{array}$ \\
\hline Biochar 2 ton ha-1 & 0,99 a & $11,15 \mathrm{a}$ \\
\hline Biochar 4 ton ha-1 & $1,67 \mathrm{ab}$ & $11,55 \mathrm{a}$ \\
\hline Biochar 6 ton ha-1 & $1,06 \mathrm{a}$ & $11,65 \mathrm{a}$ \\
\hline $\begin{array}{l}\text { Biochar } 2 \text { ton ha-1 }+ \\
\text { pupuk hayati }\end{array}$ & $1,28 \mathrm{ab}$ & $11,45 \mathrm{ab}$ \\
\hline $\begin{array}{l}\text { Biochar } 4 \text { ton } \text { ha }^{-1+} \\
\text { pupuk hayati }\end{array}$ & $2,38 \mathrm{~b}$ & $12,50 \mathrm{c}$ \\
\hline $\begin{array}{l}\text { Biochar } 6 \text { ton } \text { ha }^{-1+} \\
\text { pupuk hayati }\end{array}$ & $2,33 \mathrm{~b}$ & $12,15 \mathrm{bc}$ \\
\hline \multicolumn{3}{|c|}{$\begin{array}{r}\text { Keterangan: Angka yang diikuti huruf sama pada } \\
\text { setiap kolom yang sama, menunjukkan } \\
\text { berbeda tidak nyata berdasarkan Uji Jarak } \\
\text { Berganda Duncan pada taraf nyata } 95 \% \text {. }\end{array}$} \\
\hline
\end{tabular}

Berdasarkan hasil percobaan (Tabel 2) pemberian biochar 4-6 ton.ha-1 dan pupuk hayati $50 \mathrm{~kg} \mathrm{ha}^{-1}$ mampu meningkatkan jumlah anakan produktif padi gogo. Aplikasi biochar 4-
6 ton ha-1 tanpa pemberian pupuk hayati belum mampu meningkatkan secara nyata jumlah anakan produktif. Hal ini menunjukkan bahwa dengan pemberian pupuk hayati peranan biochar lebih optimal dalam peningkatan pertumbuhan tanaman. Hal ini sejalan dengan hasil penelitian Win et al. (2019) bahwa perlakuan biochar jerami padi dan pupuk hayati Bacillus pumilus strain TUAT-1 mampu meningkatkan jumlah anakan padi.

Berdasarkan data pada Tabel 3 menunjukkan bahwa perlakuan biochar dan pupuk hayati meningkatkan secara nyata hasil tanaman padi gogo berupa berupa terhadap bobot gabah kering giling dan bobot 1000 butir. Pemberian biochar yang dikombinasikan dengan pupuk hayati meningkatkan lebih tinggi bobot gabah kering giling dan bobot 1000 butir dibandingkan dengan perlakuan biochar saja. Hal ini didukung oleh Youseef $e t$ al. (2017) bahwa perlakuan kombinasi anatara pupuk hayati dan biochar serta pupuk mineral (NP) meningkatkan secara nyata hasil tanaman bawang putih dibandingkan perlakuan tunggal pupuk hayati atau biochar atau pupuk mineral saja.

Perlakuan biochar dengan dosis 4 ton ha-1 yang dikombinasikan dengan pupuk hayati memberikan hasil padi gogo lebih baik dibandingkan perlakuan lainya yaitu bobot gabah kering giling sebesar 23,22 g per rumpun atau setara dengan 5,8 ton ha- ${ }^{-1}$ dan bobot 1.000 butir sebesar $23,59 \mathrm{~g}$.

Tabel 3 Pengaruh biochar dan pupuk hayati terhadap bobot gabah kering giling dan bobot 1000 butir

\begin{tabular}{|c|c|c|c|}
\hline \multirow{2}{*}{ Perlakuan } & \multicolumn{2}{|c|}{ Rata-rata bobot gabah kering giling } & \multirow{2}{*}{$\begin{array}{l}\text { Bobot } 1000 \text { Butir } \\
\text { (gram) }\end{array}$} \\
\hline & Gram/rumpun & Ton/Hektar & \\
\hline Biochar 2 t ha $^{-1}$ & $16,99 a$ & 4,250 & $18,44 a$ \\
\hline Biochar 4 t ha-1 & $17,95 b$ & 4,491 & $22,52 b$ \\
\hline Biochar 6 t ha $^{-1}$ & $17,00 \mathrm{ab}$ & 4,250 & $20,26 a b$ \\
\hline Biochar 2 t ha $^{-1}+$ pupuk hayati & $20,31 b c$ & 5,075 & $22,54 b$ \\
\hline Biochar 4 tha $^{-1}+$ pupuk hayati & $23,22 \mathrm{c}$ & 5,808 & $23,59 \mathrm{c}$ \\
\hline Biochar 6 tha $^{-1}+$ pupuk hayati & $20,34 c$ & 5,083 & $22.95 \mathrm{bc}$ \\
\hline
\end{tabular}

Keterangan : Angka rata-rata yang diikuti huruf sama pada setiap kolom yang sama, menunjukkan berbeda tidak nyata berdasarkan Uji Jarak Berganda Duncan pada taraf nyata 95\%. 


\section{KESIMPULAN}

Berdasarkan hasil penelitian menunjukkan bahwa aplikasi biochar $\left(2,4\right.$ dan 6 ton.ha-1 $\left.{ }^{-1}\right)$ yang dikombinaksikan dengan pupuk hayati yang mengandung konsorsium isolat bakteri pemfiksasi N (Azotobacer chroococum, A. vilandii, dan Azospirilum sp.) dan mikroba pelarut $\mathrm{P}$ (Pseudomonas cepaceae dan Penicillium sp.) dengan takaran $50 \mathrm{~kg} \mathrm{ha}^{-1}$ meningkatkan secara nyata pertumbuhan dan hasil tanaman padi gogo.

Perlakuan biochar dan pupuk hayati ini lebih baik pengaruhnya dibandingkan dengan perlakuan biochar saja (tanpa pupuk hayati). Biochar dosis 4 ton ha-1 yang dikombinasikan dengan pupuk hayati $50 \mathrm{~kg} \mathrm{ha}^{-1}$ memberikan hasil padi gogo lebih baik dibandingkan perlakuan lainya yaitu bobot gabah kering giling sebesar 23,22 g per rumpun atau setara dengan 5,8 ton ha-1. Perlakuan ini juga memberikan bobot 1000 butir yang lebih baik $(23,59 \mathrm{~g})$ dibandingkan dengan perlakuan lainnya.

\section{UcapanTerimaksih}

Terima kasih kepada Kemenristekdikti yang telah mendanai Penelitian Terapan tahun 2019 (021/UN6.E/LT/2019). Terima kasih disampaikan kepada Rektor UNPAD, Dekan Fakultas Pertanian dan Direktur Riset dan Pengabdian Kepada Masyarakat UNPAD atas dukungan dan kerjasamanya. Ucapan terima kasih juga kepada saudara Muhamad Iqbal Kusma Sudana dan tim yang telah banyak membantu pelaksanaan di lapangan serta semua pihak yang telah membantu kelancaran penelitian ini.

\section{DAFTARPUSTAKA}

Arabi, Z., H. Eghtedaey, B. Gharehchmaghloo and A. Faraji. 2018. Effects of biochar and bio-fertilizer on yield and qualitative properties of soybean and some chemical properties of soil.
Arabian Journal of Geosciences 11:672. $1-9$.

Chan, K.Y.; Zwieten, L.V.; Meszaros, I.A.; Downie, C. and Joseph, S. 2007. Agronomic values of green waste biochar as a soil amendment. Aust. J. Soil Res., 45(8): 629-634.

Demise, W., Z. Liu, and M. Chang. 2014. Effect of biochar on carbon fractions and enzyme activity of red soil. Catena, 121: 214-221.

Egamberdieva, D., S. Wirth, U. Behrendt, E. F. Abd_Allah and G. Berg. 2016. Biochar treatment resulted in a combined effect on soybean growth promotion and a shift in plant growth promoting rhizobacteria. Frontiers in Microbiology, 7 (209): 1-11

Fitriatin, B.N., R. Silpanus, E.T. Sofyan, A. Yuniarti, and T. Turmuktini. 2019. Effect of microbial fertilizers and dosage of NPK on growth and yield of upland rice (Oryza sativa L.). International Journal of Environment, Agriculture and Biotechnology, 4(4): 899-902.

Lehmann, J. and Joseph, S. 2009. Biochar for environmental management: an introduction. In Lehmann, J. and Joseph, S. (eds), Biochar for Environmental Management-Science and Technology. Earthscan Publisher, London. p. 1-12.

Liu, Z., X. Chen, Y. Jing, Q. Li, J. Zhang and Q. Huang. 2014. Effects of biochar amendment on rapeseed and sweet potato yields and water stable aggregate in upland red soil. Catena, 123: 45-51.

Peng, X, L.L. Ye, C.H. Wang, H. Zhou, and B. Sun. 2011. Temperature and duration dependent rice straw derived Biochar: Characteristic and its effects on soil properties of an Ultisol in southern China. Tillage Res., 112: 159-166. 
Rajakumar, R. and J. Sankar. 2016. Biochar for sustainable agriculture - a Review. International Journal of Applied and Pure Science and Agriculture. 2 (9): 173-184.

Rao, N. S. 1994. Mikroorganisme Tanah dan Pertumbuhan Tanaman. Penerjemah: Susilo, H. Universitas Indonesia Press, Jakarta.

Win, K.T., K. Okazaki, T. Ookawa, T. Yokoyama, Y. Ohwakil. 2019. Influence of ricehusk biochar and Bacillus pumilus strain TUAT-1 on yield, biomass production, and nutrient uptake in two forage rice genotypes. PLoS One. 14(7): $1-21$

Youseef, M.E.A., I.A.S. Al-Easily and D.A.S. Nawar. 2017. Effect of mineral fertilizers, biofertilizers and biochar application on production of garlic grown in sandy soil condition. Egypt. J. Hort, 44 (2): 165 - 181 